\title{
Perbedaan Pendapatan Peternak Ayam Broiler Pola Kemitraan dan Mandiri di Wanasaba Lombok Timur
}

\author{
Khaerul Wathon \\ Universitas Hamzanwadi \\ khaerul.wathan@gmail.com
}

\begin{abstract}
Abstrak
Penelitian ini bertujuan untuk mengetahui perbedaan pendapatan yang diperoleh peternak ayam broiler pola kemitraan dan pola mandiri di Kecamatan Wanasaba Lombok Timur. Jenis penelitian ini adalah kuantitatif deskriptif, yaitu jenis penelitian yang sifatnya membandingkan perbedaan pendapatan yang diperoleh peternak ayam broiler pola kemitraan dan pola mandiri di Kecamatan Wanasaba Lombok Timur. Populasi dalam penelitian ini adalah para peternak yang bermitra dan mandiri di Kecamatan Wanasaba Kabupaten Lombok Timur, dan sampel penelitian ini sebanyak 15 peternak pola kemitraan dan 15 peternak pola mandiri. Analisis data yang digunakan adalah uji-t untuk mengetahui perbedaan pendapatan peternak ayam broiler pola kemitraan dan pola mandiri. Hasil yang diperoleh berdasarkan penelitian yang telah dilakukan yaitu pendapatan yang diperoleh peternak ayam broiler pola kemitraan dengan rata-rata sebesar Rp.22.098.994, sedangkan peternak ayam broiler pola mandiri dengan ratarata sebesar Rp.12.342.833. Berdasarkan hasil uji hipothesis didapatkan bahwa t-hitung lebih besar dibandingkan dengan t-tabel, dimana t-hitung -4,82, dan t-tabel 1,761. Dapat disimpulkan bahwa Ha diterima Ho ditolak, dengan demikian secara meyakinkan berdasarkan uji t terbukti bahwa terdapat perbedaan signifikan pendapatan peternak ayam broiler pola kemitraan dan pola mandiri pada taraf kepercayaan $\alpha=5 \%$.
\end{abstract}

Kata Kunci: Ayam Broiler, Pola Kemitraan, Pola Mandiri, Pendapatan

\begin{abstract}
This study aims to determine the difference in income obtained by broiler breeders in partnership and independent patterns in Wanasaba District, East Lombok. This type of research is quantitative descriptive, which is a type of research that compares the differences in income obtained by broiler breeders with partnership and independent patterns in Wanasaba District, East Lombok. The population in this study were partnered and independent breeders in Wanasaba District, East Lombok Regency, and the sample of this study was 15 partnership breeders and 15 independent farmers. Analysis of the data used is the t-test to determine the difference in the income of broiler breeders in partnership and independent patterns. The results obtained based on the research that has been done, namely the income obtained by broiler breeders with a partnership pattern with an average of Rp.22,098,994, while the independent pattern broiler breeder with an average of Rp.12,342,833. Based on the results of the hypothesis test, it was found that the t-count is greater than the $\mathrm{t}$-table, where the $\mathrm{t}$-count is -4.82 , and the $\mathrm{t}$-table is 1.761 . It can be concluded that Ha accepted Ho is rejected, thus convincingly based on the $t$ test it is proven that there is a significant difference in the income of broiler breeders in partnership and independent patterns at the level of confidence $=5 \%$.
\end{abstract}


Keywords: Broiler Chicken, Partnership Pattern, Independent Pattern, Income.

\section{Pendahuluan}

Usaha peternakan ayam broiler merupakan salah satu jenis usaha yang sangat potensial dikembangkan. Hal ini tidak lepas dari berbagai keunggulan yang dimiliki oleh ayam broiler, antara lain masa produksi yang relatif pendek yaitu kurang lebih 32-35 hari, harga yang relatif murah, permintaan yang semakin meningkat serta berbagai keunggulan lain dibandingkan unggas lainnya. Ada beberapa pola peternak ayam broiler antara lain; pola mandiri, pola kemitraan inti plasma dan pola koperasi. Peternak mandiri prinsipnya menyediakan seluruh input produksi dari modal sendiri dan bebas memasarkan produknya. Pengambilan keputusan mencakup kapan memulai beternak dan memanen ternaknya, serta seluruh keuntungan dan risiko ditanggung sepenuhnya oleh peternak (Supriyatna, dkk, 2006).

Faktor yang menyebabkan usaha peternakan ayam broiler tetap dikelola secara mandiri oleh sebagian besar peternak karena pemeliharaannya cukup mudah, waktu pemeliharaan relatif singkat ( \pm 4 minggu) karena sistim pemasarannya dalam bentuk ekoran, dan tingkat pengembalian modal relatif cepat. Namun selain itu ada beberapa hal yang menjadi kendala seperti, sarana produksi kurang, manajemen pemeliharaan/keterampilan peternak yang belum memadai, modal relative terbatas, dan risiko pemasaran/penjualan cukup besar. Usahanya tergantung situasi dan cenderung spekulatif, dimana besar kemungkinan untuk memperoleh keuntungan yang tinggi, tetapi besar pula kemungkinan untuk menderita kerugian.

Pola kemitraan usaha peternakan ayam broiler yang dilaksanakan dengan pola inti plasma, yaitu kemitraan antara peternak mitra dengan perusahaan mitra, dimana kelompok mitra bertindak sebagai plasma, sedangkan perusahaan mitra sebagai inti. Pada pola inti plasma kemitraan ayam broiler yang berjalan selama ini, perusahaan mitra menyediakan sarana produksi peternakan (sapronak) berupa: DOC, pakan. obatobatan/vitamin, bimbingan teknis dan memasarkan hasil, sedangkan plasma menyediakan kandang dan tenaga kerja.

Adanya ketidakadilan kemitraan ayam broiler biasanya terjadi karena adanya perbedaan kekuatan posisi tawar antara kelompok mitra (peternak) sebagai plasma dengan perusahaan mitra sebagai inti, sehingga pihak yang kuat mengeksploitasi pihak yang lemah. Walaupun dalam pedoman pelaksanaan kemitraan telah diatur sedemikian 
rupa, tapi kenyataan menunjukkan bahwa kemitraan belum dapat memberikan pendapatan yang sesuai dengan harapan, khususnya bagi peternak. Kemitraan yang seharusnya bersifat win-win solution (saling menguntungkan) belum tercapai, sehingga dalam upaya mengembangkan kemitraan yang tangguh dan modern diperlukan strategi untuk memperbaiki fondasi perkembangan kemitraan yang lebih mendasar (Angriani, 2011).

Meskipun ada kelebihan dan kekurangan dari masing-masing pola peternakan ayam broiler tersebut tapi bukan semata-mata itu faktor yang mendasari keberhasilan seorang peternak ayam broiler. Faktor yang paling penting yang mendasari keberhasilan seorang peternak ayam broiler adalah padaproses produksi dimulaisampai dengan panen. Oleh karena itu sebagai peternak, harus memiliki pengetahuan dan keterampilan yang cukup mengenai manajemen usaha agar berbagai masalah dapat diminimalisir atau dihindari. Kenyataan di lapangan, khususnya di peternak ayam broiler pola kemitraan di Kecamatan wanasaba Kabupaten Lombok Timur tidak selamanya plasma atau peternak yang masuk dalam kemitraan ini biasanya memperlihatkan hasil yang positif. Sebagian dari peternak bahkan ada yang mengalami kerugian atau minus sedangkan sebagaian lainnya bisa mencapai hasil yang sangat maksimal.

Keadaan yang berbeda itu, menunjukkan bahwa ada faktor-faktor yang berpengaruh terhadap keberhasilan peternakan ayam broiler pola kemitraan dan pola mandiri di Kecamatan wanasaba Kabupaten Lombok Timur. Masalah yang terkadang dijumpai adalah hubungan kemitraan yang tidak saling menguntungkan, hal ini terjadi karena perusahaan memiliki posisi yang lebih kuat dibandingkan dengan peternak dalam hal permodalan, teknologi, pasar, dan manajemen sehingga peternak seolah-olah dijadikan pekerja oleh perusahaan inti. Persoalan lainnya bagi peternak plasma adalah pengalaman selama mengikuti kemitraan tidak selalu memperoleh pelayanan yang memuaskan. Peternak tidak mempunyai kekuatan tawar dalam hal penetapan harga kontrak, dalam penyediaan DOC, sering bermasalah dengan kualitas DOC yang kurang baik namun peternak hanya bisa menerima (Angriani, 2011).

Sedangkan pada pola mandiri memiliki kendala dalam mendatangkan langsung input- input yang dibutuhkan secara langsung dan menerapkan sistem manajerialnya sendiri, sehingga total biaya produksi ditanggung langsung oleh peternak. Pada pola usaha mandiri, seluruh bentuk risiko yang terjadi harus ditanggung oleh peternak karena 
besarnya kuntungan maupun kerugian diterima langsung oleh peternak, akibat tidak menjalin kerjasama dengan pihak lain. Secara umum, pola usaha mandiri lebih peka terhadap total produksi, fluktuasi harga ayam broiler dan harga input-input di pasaran (Santoso dan Sudaryani, 2009).

Penelitian terkait yang membahas tentang peternakan pola kemitraan dan pola mandiri sudah banyak dilakukan. Seperti penelitian Salam, Muis, \& Rumengan (2009) tentang analisis finansial usaha peternakan ayam broiler pola kemitraan. Ada juga penelitian Sirajuddin (2008) tentang sistem bagi hasil pada peternak ayam pedaging pola kemitraan di Kabupaten Gowa, Provinsi Sulawesi Selatan. Penelitian Supriyatna, Wahyuni, \& Rusastra (2014) tentang analisis kelembagaan kemitraan usaha ternak ayam ras pedaging (studi kasus di Propinsi Bali). Ada penelitian Angriani (2011) tentang perbandingan pendapatan antara peternak mitra dan peternak mandiri ayam broiler di Kabupaten Bungo.

Secara umum penelitian ini membahas bagaimana pola kemitraan dan mandiri, tetapi tidak berbicara secara khusus tentang perbedaan penghasilan dari sisi kuatitatifnya terutama di Lombok Timur Nusa Tenggara Barat. Oleh karena itu penelitian ini urgensinya pada aspek tersebut. Permasalahan pada peternakan ayam broiler pola bermitra dan pola mandiri selama ini di lapangan sangat penting diketahui, karena menjadi dasar untuk mengembangakan dan mengambil keputusan dalam usahanya secara tepat baik dengan berpola mitra maupun berpola mandiri. Adapun tujuan yang ingin dicapai dalam penelitian ini adalah untuk mengetahui perbedaan pendapatan peternak ayam broiler pola kemitraan dan mandiri di Kecamatan Wanasaba Kabupaten Lombok Timur, dan untuk mengetahui tingkat perbedaan pendapatan peternak ayam broiler pola kemitraan dan mandiri di Kecamatan Wanasaba Kabupaten Lombok Timur.

\section{Metode Penelitian}

Metode yang digunakan dalam penelitian ini adalah metode kuantitatif dengan pendekatan komparatif. Penelitian komparatif adalah penelitian yang bersifat membandingkan. Penelitian ini dilakukan untuk membandingkan persamaan dan perbedaan dua atau lebih fakta-fakta dan sifat-sifat objek yang diteliti berdasarkan kerangka pemikiran tertentu (Sugiyono, 2016). Pada penelitian ini variabelnya masih mandiri tetapi untuk sampel yang lebih dari satu atau dalam waktu yang berbeda. 
Menurut Nazir (2005: 58) penelitian komparatif adalah sejenis penelitian deskriptif yang ingin mencari jawaban secara mendasar tentang sebab-akibat, dengan menganalisis faktor-faktor penyebab terjadinya ataupun munculnya suatu fenomena tertentu.

Populasi dalam penelitian ini adalah seluruh peserta peternak ayam broiler di Kecamatan Wanasaba. Adapun peternak ayam broiler pola kemitraan berjumlah 15 orang dan peternak ayam broiler pola mandiri berjumlah 15 orang semua tersebar di kecamatan wanasaba. Sampel yang digunakan dalam penelitian sebanyak 30 orang, semua anggota populasi dijadikan sampel penelitian. Oleh karena itu sampel yang diambil untuk penelitian ini sebanyak 30 orang yang terbagai 15 orang peternak berpola kemitraan dan 15 peternak berpola mandiri. Jadi sampel yang diambil dalam penelitian ini adalah peternak ayam broiler pola kemitraan dan peternak ayam broiler pola mandiri. Teknik pengumpulan data yang digunakan pada penelitian ini adalah observasi, wawancara, dan sumber kepustakaan. Untuk mengukur tingkat pendapatan dilakukan dengan menggunakan pendekatan teori keuntungan dimana persamaan keuntungan dirumuskan sebagai berikut:

$$
\begin{array}{ll}
\pi & =\mathrm{TR}-\mathrm{TC} \text { TR }=\mathrm{Y} . \mathrm{Py} \\
\mathrm{TC} & =\mathrm{TFC}+\mathrm{TVC}
\end{array}
$$

Selanjutnya untuk mengetahui perbedaan tingkat keuntungan/pendapatan digunakan pengujian hipotesis secara statistik dengan uji-t 2 arah. Hipotesis diuji dengan menggunakan uji t di mana untuk menguji hipotesis pertama yaitu perbedaan pendapatan pada peternak ayam broiler pola kemitraan dan pendapatan pada peternak ayam broiler pola kemitraan digunakan uji-t dua arah.

\section{Pembahasan}

\section{Biaya Produksi}

Biaya merupakan dasar dalam penentuan harga, sebab suatu tingkat harga yang tidak dapat menutupi biaya akan mengakibatkan kerugian. Sebaliknya, apabila suatu tingkat harga melebihi semua biaya, baik biaya produksi, biaya operasi maupun biaya non operasi akan menghasilkan keuntungan. Pada saat produksi dimulai maka saat itu pula peternak akan mengeluarkan biaya produksi. Hal ini sesuai dengan pendapat yang dikemukakan Rasyaf (2001) bahwa sejak awal anak ayam masuk sebagai tanda 
dimulainya kegiatan produksi dikandang yang bersangkutan maka saat itu pula biaya produksi dikandang tersebut mulai sudah terbentuk.

Biaya produksi dapat digolongkan dalam biaya tetap dan biaya tidak tetap. Biaya tetap adalah biaya yang jumlahnya tetap dan tidak tergantung pada besar kecilnya jumlah produksi. Sedangkan biaya variabel adalah biaya yang berubah-ubah mengikuti besar kecilnya volume produksi, misalnya pengeluaran untuk sarana produksi biaya pengadaan bibit, pupuk, obat- obatan, pakan dan lain sebagainya (Soekartawi, 2016).

Adapun biaya produksi pada peternakan ayam broiler pola kemitraan dan mandiri di Kecamatan Wanasaba Lombok Timur sebagai berikut:

a. Biaya Tetap (FC)

Biaya tetap adalah biaya tetap yang terlibat dalam produksi dan tidak berubah meskipun ada perubahan jumlah daging yang dihasilkan. Termasuk biaya penyusutan, seperti penyusutan alat-alat kandang (tempat makan, tempat minum dan lain-lain), penyusutan kandang, bunga atas pinjaman, pajak dan sejenisnya dan biaya lain-lainnya. Hal ini sesuai dengan pendapat Rasyaf (2001) bahwa biaya tetap dalam usaha peternakan ayam broiler adalah biaya tetap yang terlibat dalam proses produksi dan tidak berubah meskipun ada perubahan jumlah daging yang dihasilkan.

b. Biaya Penyusutan Kandang

Biaya penyusutan kandang merupakan komponen biaya tetap tertinggi yang dikeluarkan peternak selama produksi. Perhitungan nilai penyusutan kandang dilakukan dengan membagi biaya yang dibutuhkan untuk pembuatan kandang dengan periode pemakaian kandang tersebut. Adapun biaya penyusutan kandang pada peternak ayam broiler pada pola kemitraan dan mandiri yang berbeda di Kecamatan Wanasaba Kabupaten Lombok Timur dapat dilihat pada tabel 1.

Tabel 1. Biaya Penyusutan Kandang Pola Kemitraan dan Mandiri di Wanasaba Lombok Timur

\begin{tabular}{ccc}
\hline \multirow{2}{*}{ No. } & \multicolumn{2}{c}{ Biaya Penyusutan Kandang } \\
\cline { 2 - 3 } & Pola Kemitraan & Pola Mandiri \\
\hline 1 & 666.666 .67 & 1.000 .000 \\
2 & 2.000 .000 .00 & 666.667 \\
3 & 2.000 .000 .00 & 1.000 .000 \\
4 & 666.666 .67 & 666.667 \\
5 & 666.666 .67 & 666.667 \\
6 & 666.666 .67 & 666.667 \\
\hline
\end{tabular}




\begin{tabular}{ccc}
\hline 7 & 2.000 .000 .00 & 1.000 .000 \\
8 & 666.666 .67 & 666.667 \\
9 & 2.000 .000 .00 & 666.667 \\
10 & 2.000 .000 .00 & 1.000 .000 \\
11 & 2.000 .000 .00 & 666.667 \\
12 & 2.000 .000 .00 & 1.000 .000 \\
13 & 2.000 .000 .00 & 1.000 .000 \\
14 & 2.000 .000 .00 & 1.000 .000 \\
15 & 666.666 .67 & 666.667 \\
\hline Rata-Rata & $\mathbf{1 . 4 6 6 . 6 6 6 . 8 0}$ & $\mathbf{8 2 2 . 2 2 2 . 4 0}$ \\
\hline
\end{tabular}

Sumber: Data Primer yang telah diolah. 2019

Tabel 1 di atas menunjukkan bahwa biaya penyusutan kandang pada peternak dengan pola kemitraan dan mandiri pada. Pada pola kemitraan rata-rata penyusutan kandangnya sebesar Rp.1.466.666.80 Sedangkan biaya penyusutan kandang pada peternak dengan pola mandiri sebesar Rp.822.222.40. Biaya penyusutan kandang dihitung dengan menggunakan metode garis lurus yaitu dengan cara membagi biaya pembuatan kandang dengan lama pemakaian. Biaya penyusutan kandang yang terbanyak adalah yang bermitra dengan perusahaan dikarenakan kandang yang bermitra dengan perusahaan harus memenuhi standar perusahaan. karena dikhawatirkan ayam yang akan dikandangkan akan mengalami stress. Pendapat ini sesuai dengan pendapat Hardjosworo dan Rukmiasih (2000) yang menyatakan bahwa ukuran luas kandang tergantung dari kepadatan jumlah populasi ternak yang dipelihara. Luas yang cukup bagi ayam untuk ruang geraknya maka tidak akan terjadi saling patuk dan stress.

Disamping itu model kandang kedua pola tersebut berbeda dimana pola yang bermitra dengan mandiri model kandang mengikuti bentuk lahan atau tidak sesuai dengan prosedur arah kandang yang baik sedangkan bentuk kandang yang bermitra dengan perusahaan bentuknya memanjang dari arah timur ke barat sesuai dengan prosedur kandang yang baik.

\section{Biaya Penyusutan Peralatan}

Tidak hanya kandang yang mengalami penyusutan tetapi peralatan kandang juga mengalami penyusutan seiring dengan berjalannya waktu. penyusutan peralatan termasuk dalam biaya tetap karena nilai peralatan kandang dari ke tahun menyusut meskipun kandang dikosongkan. Adapun biaya penyusutan peralatan pada peternak 
ayam broiler pada pola kemitraan yang berbeda di Kecamatan Wanasaba Kabupaten Lombok Timur dapat dilihat pada tabel 2.

Tabel 2. Biaya Penyusutan Peralatan Pola Kemitraan dan Mandiri di Wanasaba Lombok Timur

\begin{tabular}{ccc}
\hline \multirow{2}{*}{ No. } & \multicolumn{2}{c}{ Biaya Penyusutan Peralatan } \\
\cline { 2 - 3 } & Pola Kemitraan & Pola Mandiri \\
\hline 1 & 333.333 & 600.000 \\
2 & 600.000 & 333.333 \\
3 & 600.000 & 600.000 \\
4 & 333.333 & 333.333 \\
6 & 333.333 & 333.333 \\
7 & 333.333 & 333.333 \\
8 & 600.000 & 600.000 \\
9 & 333.333 & 333.333 \\
10 & 600.000 & 333.333 \\
11 & 600.000 & 600.000 \\
12 & 600.000 & 333.333 \\
13 & 600.000 & 600.000 \\
14 & 600.000 & 333.333 \\
15 & 600.000 & 600.000 \\
Rata-Rata & 333.333 & 333.333 \\
\hline
\end{tabular}

Sumber: Data Primer yang telah diolah. 2019

Tabel 2 menunjukkan bahwa biaya penyusutan peralatan kandang pada peternak dengan pola kemitraan rata-rata sebesar Rp.493.333. Sedangkan biaya penyusutan peralatan kandang pada peternak dengan pola mandiri rata-rata sebesar Rp.439.999. Besar kecilnya biaya penyusutan peralatan kandang yang ditanggung tiap periodenya dipengaruhi oleh skala usaha. Besarnya nilai penyusutan peralatan kandang diperoleh dari nilai investasi yang dikeluarkan dibagi dengan masa pemakaian. Biaya penyusutan peralatan kandang pada pola mandiri lebih rendah dibandingkan yang bermitra dengan perusahaan. Perbedaan tersebut dikarenakan jumlah ternak yang dimiliki oleh mandiri lebih kecil dibanding yang pola kemitraan. Pendapat ini sesuai dengan pendapat Cahyono (2004) yang menyatakan bahwa kebutuhan tempat pakan dan minum tergantung dari jumlah ayam yang dipelihara dan umur ayam. 


\section{Biaya Variabel (VC)}

Biaya variabel atau disebut dengan biaya tidak tetap biasa didefinisikan sebagai biaya yang dikeluarkan atau ditanggung oleh peternak selama masa produksi yang besar kecilnya dipengaruhi oleh skala atau jumlah produksi. Artinya bahwa semakin tinggi skala produksi maka akan semakin meningkat pula biaya variabel yang harus ditanggung oleh peternak selama masa produksi berlangsung. Hal ini sesuai dengan pendapat Daniel (2002) bahwa biaya variabel adalah biaya yang berubah-ubah mengikuti besar kecilnya volume produksi. misalnya pengeluaran untuk sarana produksi biaya pengadaan bibit. pupuk. obat-obatan. pakan dan lain sebagainya. Yang termasuk dalam komponen biaya variabel untuk usaha peternakan ayam broiler yaitu bibit (DOC), biaya pakan, biaya vaksin dan obat-obatan, biaya tenaga kerja, biaya listrik, dan biaya lain-lain yang dikeluarkan untuk mendukung kegiatan operasional lainnya.

\section{a. Biaya Bibit (DOC)}

Bibit merupakan faktor yang tidak bisa diabaikan. bibit ayam broiler yang berkualitas baik yaitu bibit dengan produksi daging yang tinggi dengan konversi pakan yang sedikit. Bibit ayam broiler yang digunakan oleh peternak dikenal sebagai DOC (Day Old Chick) ayam broiler pedaging. Bibit ini umumnya berasal dari ternak golongan commercial stock yang sudah diketahui prestasinya dalam penyediaan bibit ayam yang bagus dimana bibit yang bagus biasanya dapat di ketahui dengan cirri-ciri berwarna cerah. bersih dan tidak cacat. pendapat serupa juga di kemukakan oleh Rasyaf (2004: 46) yang menyatakan bahwa pedoman untuk memilih DOC yaitu anak ayam harus berasal dari induk sehat agar tidak membawa penyakit bawaan; ukuran atau bobot ayam yaitu sekitar 35 sampai 40 gram; anak ayam memiliki mata yang cerah dan bercahaya. aktif serta tampak tegar; tidak memperlihatkan cacat fisik seperti kaki bengkok. mata buta atau kelainan fisik lainnya yang mudah dilihat dan tidak ada lekatan tinja di duburnya. Adapun rata-rata biaya bibit (DOC) peternakan di Kecamatan Wanasaba Kabupaten Lombok Timur dapat dilihat dari biaya yang dikeluarkan oleh peternak yang bermitra dengan rata-rata total biaya DOC Rp. 30.000 .000 dengan harga per ekornya Rp. 6.250. Sedangkan biaya yang dikeluarkan oleh peternak yang pola mandiri yakni total biaya DOC rata-rata Rp.22.916.667 dengan harga per ekornya Rp. 5.500. Biaya DOC yang bermitra dengan perusahaan lebih mahal dibanding dengan yang 
mandiri. Hal ini mungkin disebabkan oleh beberapa faktor antara lain harga bibit yang dibeli.

\section{b. Biaya Pakan}

Pakan merupakan salah satu faktor yang mempengaruhi tinggi rendahnya laju pertumbuhan broiler. Dalam usaha peternakan ayam broiler. pakan ternak memegang peranan yang sangat penting dalam menjamin kelangsungan hidup usaha tersebut. Pakan merupakan hal yang sangat penting dan lebih penting lagi adalah harga dari pakan tersebut. Hal ini sesuai dengan pendapat Rasyaf (2001). yang menyatakan bahwa biaya variabel terdiri dari biaya bibit ayam yang porsinya antara 10-16\% dari total biaya produksi. biaya kesehatan dalam kodisi normal porsinya hanya 1-2\%. serta biaya pakan yang porsinya $70-80 \%$ dari total biaya produksi. Dengan demikian. keberadaan pakan sangat mempengaruhi keberhasilan usaha peternakan ayam broiler.

Harga pakan yang diberikan akan sangat berpengaruh terhadap biaya yang ditanggung pada usaha ternak tersebut. Besarnya biaya pakan yang dikeluarkan oleh peternak di Kecamatan Wanasaba Kabupaten Lombok Timur diketahui bahwa biaya pakan yang bermitra dengan perusahaan perseorangan total biaya pakan rata-rata yakni Rp.53.460.000 dengan rata-rata jumlah pemakaian 198 karung dan setiap karung itu mempunyai harga Rp.270.000/karung. Sedangkan biaya pakan yang mandiri memiliki biaya pakan rata-rata sebsear Rp.48.780.000 dengan jumlah pemakaian 181 karung dan setiap karung itu mempunyai harga Rp.270.000/karung. Biaya pakan yang paling tinggi adalah yang bermitra dengan perusahan dikarenakan jumlah pemakaian dalam setiap periode banyak dibanding dengan yang mandiri. disamping pola mandiri membeli pakan dengan eceran atau tidak dalam partai besar.

\section{c. Biaya Vaksin dan Obat-Obatan}

Untuk memperoleh hasil ayam broiler yang menguntungkan. maka salah satu cara yang harus dilakukan dengan memperhatikan kondisi kesehatan ayam yang dipelihara. Pencegahan secara cepat dan tepat dapat menghindarkan kemungkinan terserang penyakit bagi broiler. Salah satu tindakan pencegahan penyakit yang dilakukan yaitu melakukan vaksinasi guna menciptakan kekebalan tubuh terhadap virus yang dapat menular. Besarnya biaya vaksin dan obat-obatan yang dikeluarkan peternak di Kecamatan Wanasaba Kabupaten Lombok Timur menunjukkan biaya vaksin dan obatobatan pada pola kemitraan rata-rata biaya sebesar yakni Rp.1.220.000. Sedangkan 
biaya vaksin dan obat-obatan pada pola mandiri yaitu rata-rata sebesar Rp.1.403.333. Biaya vaksin dan obat-obatan yang tertinggi yaitu yang mandiri. Hal ini disebabkan yang mandiri memiliki banyak macam obat-obatan dibanding dengan yang bermitra dengan perusahaan. disamping itu yang bermitra dengan perusahaan memiliki standar dan ketentuan dalam pemberian obat-obatan. demi penanganan penyakit untuk meningkatkan penghasilan. Senada dengan pendapat tersebut Rasyaf (2004) menyatakan bahwa pengobatan terhadap ayam yang sakit dilakukan dengan pemberian obat sesuai anjuran mantri hewan serta melakukan isolasi terhadap ayam sakit dengan tujuan menghindari penularan penyakit.

d. Biaya Listrik

Pada usaha peternakan ayam broiler. kebutuhan listrik digunakan sebagai penerangan serta menghangatkan tubuh ayam broiler pada malam hari saat udara dingin dan juga penggerak dinamo untuk air. listrik salah satu penunjang peningkatan produktivitas usaha peternakan. besarnya biaya tergantung pemakaian tiap bulannya. Adapun biaya listrik yang dikeluarkan peternak di Kecamatan Wanasaba Kabupaten Lombok Timur menunjukkan biaya listrik yang bermitra dengan perusahaan memiliki rata- rata biaya listrik adalah Rp.2.736.000/tahunnya atau rata-rata tiap bulanya Rp.228.000. Sedangkan biaya listrik yang mandiri memiliki biaya rata-rata sebesar Rp.2.736.000/tahunnya atau rata-rata tiap bulanya Rp.228.000. Biaya listrik yang bermitra dan mandiri memiliki rata- rata pengeluaran yang sama.

e. Biaya Tenaga Kerja

Kebutuhan tenaga kerja pada usaha ternak ayam broiler juga penting. Hal ini disebabkan karena pada usaha ternak ayam broiler tenaga kerja sibuk pada waktu- waktu tertentu. yaitu pada saat pemberian pakan. membersihkan dan pengawasan di malam hari jika perlu. Adapun biaya tenaga kerja yang dikeluarkan peternak di Kecamatan Wanasaba Kabupaten Lombok Timur dapat dilihat bahwa biaya tenaga kerja pada pola kemitraan adalah rata-rata senilai Rp.1.046.667. Sedangkan pada pola mandiri rata-rata sebesar Rp.1.296.667.

f. Total Biaya (TC)

Biaya total merupakan keseluruhan biaya yang dikeluarkan oleh peternak ayam broiler selama proses produksi (satu periode). Biaya ini merupakan hasil penjumlahan antara biaya tetap dengan biaya variabel selama satu periode. Hal ini sesuai dengn 
pendapat DH dan Sukoco (1997) yang menyatakan bahwa biaya total adalah seluruh biaya yang dikeluarkan oleh perusahaan atau peternak untuk proses produksi atau dengan kata lain biaya total merupakan jumlah dari biaya variabel dan biaya tetap. Adapun biaya total produksi yang dikeluarkan oleh peternak di Kecamatan Wanasaba Kabupaten Lombok Timur dapat dilihat pada total biaya produksi tersebut biaya variabel merupakan biaya yang paling besar dikeluarkan oleh peternak dalam masa satu periode produksi dibandingkan dengan biaya tetap. Biaya variabel merupakan komponen biaya terbesar karena berkaitan dengan jumlah skala usaha atau jumlah ternak yang dipelihara peternak dimana semakin tinggi jumlah ternak makin tinggi juga biaya variabel yang dikeluarkan.

\section{Penerimaan Hasil Produksi}

Penerimaan dari usaha ayam pedaging diperoleh dari penjualan daging dan penjualan feses. Menurut Himawati (2006: 75) bahwa penerimaan merupakan hasil kali antara harga dengan total produksi dengan rumus sebagai berikut $\mathrm{TR}=\mathrm{Pq} \times \mathrm{Q}$. dimana TR adalah total revenue. $\mathrm{Pq}$ adalah harga per satuan unit dan $\mathrm{Q}$ adalah total produksi. Apabila hasil produksi peternakan dijual ke pasar atau ke pihak lain. maka diperoleh sejumlah uang sebagai produk yang terjual tersebut. Besar atau kecilnya uang diperoleh tergantung dari pada jumlah barang dan nilai barang yang dijual. Barang yang dijual akan bernilai tinggi bila permintaan melebihi penawaran atau produksi sedikit. Jumlah produk yang dijual dikalikan dengan harga yang ditawarkan merupakan jumlah uang yang diterima sebagai ganti produk peternakan yang dijual inilah yang dinamakan penerimaan (Rasyaf, 2001). Pada usaha peternakan ayam broiler di Kecamatan Wanasaba Kabupaten Lombok Timur sumber penerimaan peternak berasal dari 2 komponen yaitu hasil penjualan daging/ayam dan hasil penjualan feses.

a. Penerimaan Hasil Penjualan Daging/Ayam

Ayam broiler memiliki pertumbuhan yang sangat pesat pada umur 1-5 minggu atau kurang dari 1 bulan dan sudah dapat dipasarkan pada umur 5-6 minggu dengan bobot hidup antara 1.3-1.7 kg. Adapun besarnya penerimaan yang didapatkan peternak dari penjualan daging/ayam di Kecamatan Wanasaba Kabupaten Lombok Timur dapat dilihat bahwa penerimaan hasil penjualan daging/ayam yang bermitra dengan p erusahaan rata-rata sebesar yakni Rp.102.957.500 dengan harga per kilonnya yakni Rp.14.700/Kg. Sedangkan yang penerimaan hasil penjualan daging/ayam yang mandiri 
memperoleh penerimaan rata-rata sebesar Rp.100.619.216 dengan harga per kilonnya Rp.14.900/Kg. Hasil penjualan daging/ayam merupakan komponen terbesar dalam penerimaan. sehingga hasil dari penjualan dapat menekan biaya produksi agar keuntungan yang diperoleh dapat maksimal sesuai apa yang diharapkan peternak.

b. Penjualan Feses

Selain penjualan daging/ayam komponen penerimaan lainnya yang didapatkan peternak dari usaha peternakan broiler adalah penjualan sisa makanan yang tidak dicerna oleh ternak dalam bentuk feses. penjualan feses dilakukan tiap periodenya dalam per karung. Adapun besarnya penerimaan yang didapat peternak dari penjualan feses di Kecamatan Wanasaba Kabupaten Lombok Timur dapat diketahui bahwa penerimaan hasil penjualan feses yang pola kemitraan rata- rata sebesar yakni Rp.480.000. Sedangkan yang penerimaan hasil penjualan feses pola mandir memperoleh penerimaan rata-rata sebesar Rp.405.000 dengan harga per karungnya Rp.3.000/Karungnya. Feses yang dihasilkan oleh ayam biasanya dijual ke petani untuk dimanfaatkan sebagai pupuk kandang untuk tanaman.

c. Total Penerimaan (TR)

Total penerimaan merupakan penjumlahan komponen penerimaan hasil produksi dinyatakan dalam bentuk rupiah yaitu penjualan daging/ayam dan penjualan feses. Adapun total penerimaan yang didapatkan peternak di Kecamatan Wanasaba Kabupaten Lombok Timur menunjukkan total penerimaan dari semua komponen yang pola kemitraan dengan perusahaan rata-rata sebesar yakni Rp.102.957.500. Sedangkan yang peternak pola mandiri rata-rata penerimaannya sebesar adalah Rp.100.619.217. Komponen penerimaan usaha peternakan ayam broiler di Kecamatan Wanasaba Kabupaten Lombok Timur yaitu bersumber dari hasil penjualan daging/ayam dan penjualan feses. Dari data tersebut juga dilihat sumber penerimaan daging/ayam yang paling besar memperoleh penerimaan adalah dari penjualan daging/ayam.

\section{Pendapatan Peternak}

Pendapatan atau keuntungan merupakan tujuan setiap jenis usaha. Keuntungan dapat dicapai jika jumlah penerimaan yang diperoleh dari hasil usaha lebih besar daripada jumlah pengeluarannya. Semakin tinggi selisih tersebut. semaking meningkat keuntungan yang dapat diperoleh. Bisa diartikan pula bahwa secara ekonomi usaha 
tersebut layak dipertahankan atau dilanjutkan. Jika situasinya terbalik. usaha tersebut mengalami kerugian dan secara ekonomis sudah tidak layak dilanjutkan. Hal ini sesuai dengan pendapat Soekartawi (2003: 32) menyatakan bahwa pendapatan (keuntungan) adalah selisih antara penerimaan dengan semua biaya. Adapun besarnya pendapatan peternak di Kecamatan Wanasaba Kabupaten Lombok Timur dapat dilihat bahwa pendapatan peternak yang bermitra dengan perusahaan sebesar Rp.12.342.833.33. Sedangkan pendapatan peternak yang pola mandiri rata-rata sebesar Rp.22.098.994.44. Hal ini ini sejalan dengan pendapat Gusasi dan Saade (2006) bahwa perbedaan pendapatan pada setiap tingkatan skala usaha sangat nyata sehingga manfaat dan keuntungan dapat diperoleh pada skala usaha yang lebih besar. Pendapatan total dan ratarata kedua kelompok pola kemitraan dan pola mandiri, yaitu pendapatan pola mandiri lebih tinggi daripada pola kemitraan dengan perusahaan

\section{Perbedaan Pendapatan Peternak Ayam Broiler Pola Kemitraan dan Mandiri di Wanasaba Lombok Timur}

Prinsip dari suatu usaha ternak ayam adalah menghasilkan produksi yang maksimal dengan menekan penggunaan biaya yang seminimal mungkin atau dengan melakukan efisiensi dalam penggunaan biaya produksi (Fadilah, 2004). Tujuan dari kegiatan usaha ternak adalah untuk memperoleh keuntungan yang setinggi mungkin dengan biaya yang serendah-rendahnya dan usaha ternak yang efisien adalah usaha ternak yang secara ekonomis menguntungkan (Saragih, 2001). Demikian juga dengan usaha ternak ayam broiler. Analisis $R / C$ merupakan salah satu cara untuk mengetahui tingkat efisiensi biaya dari suatu usahaternak.

Biaya produksi usaha ternak ayam yang dikeluarkan oleh setiap peternak berbeda tergantung dari produksi yang diusahakan. penggunaan tenaga kerja. jenis bibit yang digunakan. penggunaan pakan. serta kondisi lingkungan (Siregar, 2005). Tingkat keberhasilan usaha ternak ayam dapat dilihat dari efisiensi penggunaan biaya produksi. Apabila peternak memperoleh keuntungan yang tinggi dari hasil usaha ternak ayam, dan keuntungan tersebut melebihi biaya produksi yang dikeluarkan oleh peternak selama proses produksi berlangsung, maka dapat dikatakan bahwa usaha ternak ayam broiler yang dilakukan menguntungkan dan biaya-biaya yang dikeluarkan efisien (Suharno, 2002). Selanjutnya usaha ternak tersebut dapat dikatakan berhasil. jika usaha ternak 
tersebut menghasilkan keuntungan yang cukup untuk membayar semua biaya yang dikeluarkan (Sutawi, 2007).

Perbandingan pendapatan antara penerimaan dengan total biaya yang dikeluarkan selama proses produksi peternak ayam boriler. Usaha ternak dikatakan efisien apabila nilai perbandingan yang diperoleh antara penerimaan dengan biaya lebih dari $1(R / C$ $>1)$. dikatakan tidak efisien apabila kurang dari $1(R / C<1)$ dan jika nilai $(R / C=1$ maka penggunaan biaya produksi berada pada titik impas (Break Even Point). Efisiensi biaya produksi usaha ternak ayam di Kecamatan Wanasaba Kabupaten Lombok Timur dapat diketahui dengan analisa $R / C$ yaitu dengan menggunakan perbandingan total penerimaan dengan total biaya produksi. Nilai efisiensi biaya produksi usaha ternak ayam broiler pola kemitraan dan pola mandiri di Kecamatan Wanasaba Kabupaten Lombok Timur disajikan pada tabel 3.

Tabel 3. Rata-rata Efisiensi Biaya Produksi Peternak Ayam Broiler Pola Kemitraan dan Pola Mandiri di Wanasaba Lombok Timur

\begin{tabular}{cllc}
\hline \multirow{2}{*}{ No. } & \multicolumn{2}{c}{ Uraian } & \multicolumn{2}{c}{ Peternak Ayam Broiler } \\
\cline { 3 - 4 } & & Pola Kemitraan & Pola Mandiri \\
\hline 1 & Penerimaan $(\mathrm{Rp})$ & $1,544,362,500$ & $1,509,288,250$ \\
2 & Biaya Produksi (Rp) & $1,359,220,000$ & $1,177,803,333$ \\
3 & R/C & 1.14 & 1.28 \\
\hline
\end{tabular}

Sumber: Data primer yang diolah, 2019)

Penerimaan pada pola kemitraan yaitu sebesar Rp.1.544.362.500, sedangkan biaya produksi Rp.1.359.220.000, sehingga diperoleh RC-Ratio sebesar 1.14. Pada pola mandiri diperoleh penerimaan sebesar Rp.1.509.288.250, dan biaya produksinya sebesar Rp.1.177.803.333, sehingga diperoleh R/C sebesar 1.28. Berdasarkan kriterianya nilai $\mathrm{R} / \mathrm{C}>1$ berarti usaha peternakan ayam broiler baik pola kemitraan maupun pola mandiri sama-sama efisien. Nilai tersebut memberikan arti bahwa setiap satu satuan rupiah yang dikeluarkan untuk biaya produksi ayam broiler memberikan penerimaan sebesar Rp.1.14 dan Rp.1.28. Dengan demikian besarnya nilai $R / C$ yang diperoleh peternak lebih dari $1(R / C>1)$, maka dapat dikatakan bahwa peternakan ayam broiler pola kemitraan dan pola mandiri di Kecamatan Wanasaba Kabupaten Lombok Timur adalah efisien. 


\section{Tingkat Perbedaan Pendapatan Peternak Ayam Broiler Pola Kemitraan dan Mandiri di Wanasaba Lombok Timur}

Berdasarkan perbedaan pendapatan peternak ayam broiler pola kemitraan dan pola mandiri menunjukkan bahwa total biaya yang dikeluarkan oleh peternak ayam broiler pola kemitraan lebih tinggi dibandingkan peternak ayam broiler pola mandiri. Untuk melihat apakah terjadi perbedaan pendapatan antara peternakan ayam broiler pola kemitraan dan pola mandiri maka dilakukan uji-t.

Tabel 4. Hasil Analisis Uji Beda Perbedaan Pendapatan Peternak Ayam Boiler Pola Kemitraan dan Mandiri di Wanasab Lombok Timur

Paired Samples Test

\begin{tabular}{|c|c|c|c|c|c|c|c|c|}
\hline & \multicolumn{5}{|c|}{ Paired Differences } & \multirow{3}{*}{$\mathbf{T}$} & \multirow{3}{*}{ Df } & \multirow{3}{*}{$\begin{array}{l}\text { Sig. (2- } \\
\text { tailed) }\end{array}$} \\
\hline & \multirow[t]{2}{*}{ Mean } & \multirow[t]{2}{*}{$\begin{array}{c}\text { Std. } \\
\text { Deviation }\end{array}$} & \multirow[t]{2}{*}{$\begin{array}{l}\text { Std. Error } \\
\text { Mean }\end{array}$} & \multicolumn{2}{|c|}{$\begin{array}{c}95 \% \text { Confidence } \\
\text { Interval of the } \\
\text { Difference } \\
\end{array}$} & & & \\
\hline & & & & Lower & Upper & & & \\
\hline $\begin{array}{l}\text { Pendapatan Pair } \\
\text { Peternak Pola } \\
\text { Kemitraan - } \\
\text { Pendapatan Peternak } \\
\text { Pola Mandiri }\end{array}$ & -9756161.1 & 7834768.167 & 2022928.442 & -14094911.1 & -5417411.11 & -4.82 & 14 & .000 \\
\hline
\end{tabular}

Sumber: Analis data primer yang diolah, 2019

Sesuai dengan hipotesis yang diajukan maka sebagai acuan adalah Ha: Ha diterima bila $t$ hitung $>\mathrm{t}$ tabel atau $-\mathrm{t}$ hitung $<-\mathrm{t}$ tabel, Ha ditolak bila $-\mathrm{t}$ tabel $>-\mathrm{t}$ hitung atau $\mathrm{t}$ tabel $>\mathrm{t}$ hitung. Karena $-\mathrm{t}$ hitung $<-\mathrm{t}$ tabel $(-4.82<1.761)$, maka Ha diterima Ho ditolak. Dengan demikian secara meyakinkan berdasarkan uji $\mathrm{t}$ terbukti bahwa terdapat perbedaan signifikan pendapatan peternak ayam broiler pola kemitraan dan pola mandiri pada taraf kepercayaan $\alpha=5 \%$. Hasil ini menunjukkan bahwa tingkat pendapatan masingmasing peternak ayam broiler berbeda sesuai dengan pola pengelolaan dengan kemitraan dan mandiri. Yang mana peternak ayam broiler pola mandiri memiliki endapatan lebih tinggi dibandingkan pendapatan peternak ayam broiler pola kemitraan. Artinya peternak ayam broiler pola mandiri lebih menguntungkan.

Budidaya peternakan ayam broiler hanya merupakan satu sub-sistem dari sistem agribisnis peternakan ayam broiler secara menyeluruh. maka peternak budidaya tidak dapat berdiri sendiri. kemudian kekuatan dan kelemahan ada pada masing-masing pihak dan masing-masing mempunyai keinginan untuk saling mengisi (Salam, dkk., 2009). Menurut Kartasasmitha (2006) kemitraan usaha ialah hubungan kerja sama antara 
berbagai pihak. baik bersifat vertikal antara usaha kecil dengan usaha menengah atau usaha besar atau bersifat horisontal pada skala usaha yang sama. dengan memperhatikan prinsip saling memerlukan. saling memperkuat. dan saling menguntungkan untuk meningkatkan efisiensi dan produktivitas dalam rangka meningkatkan daya saing. Senada dengan hal tersebut bahwa kemitraan usaha mendukung efisiensi ekonomi karena pihak-pihak yang bermitra masing-masing menawarkan sisi keunggulan yang dimilikinya dalam upaya memperkuat mekanisme pasar (Saptana, dkk. 2009). Analisi $\mathrm{R} / \mathrm{C}$ ratio menunjukkan bahwa usaha ternak pola mandiri lebih menguntungkan dibandingkan usaha ternak pola kemitraan. R/C ratio untuk peternak mandiri sebesar 1.51 yang berarti setiap Rp.1 biaya yang dikeluarkan akan menghasilkan penerimaan sebesar Rp.1.51. Sedangkan peternak bermitra memiliki R/C ratio sebesar 1.33 yang berarti setiap Rp.1 biaya yang dikeluarkan akan menghasilkan penerimaan sebesar Rp.1.33.

Menurut pendapat di atas peternak ayam broiler dengan pola kemitraan dan polamandiri masing-masing memiliki kelebihan dand kekurangan. Khusus untuk peternak mandiri mempunyai pilihan-pilihan untuk menyalurkan hasil produksinya yaitu ke broker dan warga sekitar. Sedangkan untuk peternak bermitra konsisten karena hanya memproduksi daging sesuai target yang diberikan perusahaan inti dan menyerahkan hasilnya untuk dipasarkan oleh perusahaan inti tersebut sehingga hasil pendapatan yang didapatkan lebih stabil. Dengaan begitupun secara otomatis akan timbul perbedaan pendapatan yang akan diperoleh oleh peternak bermitra dan peternak mandiri.

\section{Kesimpulan}

Pendapatan yang didapat oleh peternak ayam broiler pola kemitraan dengan total pendapatan Rp.185.142.500, dan rata-rata sebesar Rp.22.098.994. Sedangkan peternak ayam broiler pola mandiri dengan total pendapatan Rp.331.484.917, dan rata-rata sebesar Rp.12.342.833. Berdasarkan hasil uji hipothesis didapatkan bahwa t-hitung lebih besar dibandingkan dengan t-tabel. dimana t-hitung -4.82. dan t-tabel 1.761. Maka dapat disimpulkan bahwa Ha diterima Ho ditolak. dengan demikian secara meyakinkan berdasarkan uji t terbukti bahwa terdapat perbedaan signifikan pendapatan peternak ayam broiler pola kemitraan dan pola mandiri pada taraf kepercayaan $\alpha=5 \%$. 


\section{Daftar Rujukan}

Angriani, Elsye Dilla. (2011). Perbandingan Pendapatan Antara Peternak Mitra dan Peternak Mandiri Ayam Broiler di Kabupaten Bungo. Skripsi. Padang: Universitas Andalas.

Cahyono, (2004). Cara Meningkatkan Budidaya Ayam Ras Pedaging (Broiler). Yogyakarta: Pustaka Nusatama.

Daniel, Moehar. (2002). Metode Penelitian Sosial Ekonomi. Jakarta: Bumi Aksara.

DH, Basu Swasta \& Sukoco. (1997). Pengantar Bisnis Modern. Yogyakarta: Liberty.

Fadilah. R. (2004). Kunci Sukses Beternak Ayam Broiler di Daerah Tropis. Jakarta: Agromedia Pustaka.

Gusasi, A., \& Saade, M. A. (2006). Analisis pendapatan dan efisiensi usaha ternak ayam potong pada usaha skala kecil. J. Agristem, 2(1), 2-3.

Hardjosworo, P.S. dan Rukmiasih. (2000). Meningkatkan Produksi Daging Unggas. Jakarta: Penebar Swadaya.

Kartasasmitha. Ginandjar. (2006). Pembangunan Untuk Rakyat: Memadukan Pertumbuhan dan Pemerataan. Jakarta: Pustaka Cidesindo.

Nazir. M. (2005). Metode Penelitian. Jakarta: Salemba Empat.

Rasyaf, M. (2001). Pengelolaan Usaha Peternakan Ayam Pedaging. Jakarta: Gramedia Pustaka Utama.

Rasyaf, M. (2004). Beternak Ayam Pedaging. Edisi Revisi. Jakarta: Penebar Swadaya.

Salam, T., Muis, M., \& Rumengan, A. E. (2009). Analisis Finansial Usaha Peternakan ayam broiler pola kemitraan. Jurnal Agrisistem, 1, 213-217.

Santoso dan Sudaryani, T. (2009). Pembibitan Ayam Ras. Bogor: PT. Penebar Swadaya.

Saptana. dkk. (2009). Strategi kemitraan Usaha dalam Rangka Peningkatan Daya Saing Agribisnis Cabai Merah di Jawa Tengah. Bogor: Badan Litbang Pertanian Departemen Pertanian.

Saragih, B. (2001). Agribisnis Berbasis Peternakan. Bogor: Pustaka Wirausaha Muda.

Sirajuddin, S. N. (2008). Sistem bagi hasil pada peternak ayam pedaging pola kemitraan di Kabupaten Gowa, Provinsi Sulawesi Selatan. Jurnal Agribisnis. VII (2), Makassar.

Siregar, A. P. (2005). Teknik Beternak Ayam Pedaging di Indonesia. Jakarta: Merdie Group.

Soekartawi, (2016). Agribisnis: Teori dan Aplikasinya. Jakarta: Rajawali Press.

Soekartawi. (2003). Teori Ekonomi Produksi dengan Pokok Bahasan Analisis Fungsi Cobb- Douglas. Jakarata: Raja Grafindo Persada.

Sugiyono, (2016). Metode Penelitian Bisnis. Bandung: Alfabeta.

Suharno. 2002. Kiat Sukses Berbisnis Ayam. Penebar Swadaya. Jakarta. 
Jurnal Humanitas

Vol. 6 No. 1, Desember 2019, hal. 15-33

Supriyatna, Y. A. N. A., Wahyuni, S., \& Rusastra, I. (2014). Analisis Kelembagaan Kemitraan Usaha Ternak Ayam Ras Pedaging (Studi Kasus di Propinsi Bali). JITV, 19(3), 830-840.

Sutawi, (2007). Pengelolaan Usaha Perternakan. Makassar: Universitas Hassanudin. 